Autumn 2009

\title{
Are Immigrants Disloyal? The Case of Mexicans in
} the U.S.

Krystof Kozak

\section{(2) OpenEdition \\ Journals}

Electronic version

URL: https://journals.openedition.org/ejas/7629

DOI: $10.4000 /$ ejas.7629

ISSN: 1991-9336

Publisher

European Association for American Studies

\section{Electronic reference}

Krystof Kozak, "Are Immigrants Disloyal? The Case of Mexicans in the U.S.", European journal of American studies [Online], 4-2 | 2009, document 3, Online since 21 October 2009, connection on 08 July 2021. URL: http://journals.openedition.org/ejas/7629 ; DOI: https://doi.org/10.4000/ejas.7629

This text was automatically generated on 8 July 2021

Creative Commons License 


\title{
Are Immigrants Disloyal? The Case of Mexicans in the U.S. ${ }^{*}$
}

\author{
Krystof Kozak
}

\section{Introduction}

1 Political loyalty is one of the key demands that the modern state places on its citizens; disloyalty can lead to disobedience, threatening its very foundations. From this perspective, immigration has always presented a challenge for the receiving country, as it tries to instill political loyalty in new migrants. State authorities have questioned the loyalty of fresh immigrants, especially in times of international crises when ties to their country of origin have become suspicious. As long as migration flows continue, the inherent tension between political loyalties to both the sending as well as the receiving country will ensure that the issue of immigrant loyalty will remain highly controversial and relevant in the debates about appropriate immigration policies.

2 In this article I will address the question to what extent the fears of immigrant disloyalty are based on reality. I will review the current literature on the issue and focus on the case study of Mexicans migrating to the United States, where immigration critics frequently resort to claims of real or potential disloyalty. This serves as a powerful argument in the discourse about immigration, as it symbolically emphasizes the otherness of immigrants as well as raises the specter of potential mass disobedience and disorder. I will present possible ways of how to assess immigrant loyalty based on various sources of field-work data, and apply them to the case of Mexican immigrants. I will then argue that current controversies about immigrant loyalty are based on an outdated understanding of political loyalty that does not capture the complex political as well as cultural ties that are relevant for immigrants from Mexico today.

3 Methodologically, I will first define a working concept for the term 'loyalty', with specific emphasis on its political aspects. I will briefly mention episodes in U.S. history where loyalty in connection with immigration became a major concern. The following section will contain a review and assessment of current charges of disloyalty aimed at migrants from Mexico. I will then present various available indicators relevant to political loyalty and apply them to immigrants from Mexico. The conclusion will 
discuss the findings and present a more accurate framework for discussions about political loyalty today.

The topic of loyalty is highly relevant, since immigration will continue to be a contested political issue, particularly in periods of economic downturn. Both the perceived and actual loyalty of immigrants will play an important role in debates concerning appropriate immigration policies. A more refined view of the concept of loyalty has the potential to mitigate some of the tensions between pro-immigrant advocates and their vocal opponents in academic and wider political discussions of immigration policies.

2. A Definition of Political Loyalty

5 Loyalty is a complex and contested term, but for the purposes of this article, I will rely on the working definition provided by John Kleinig. For Kleinig loyalty can be characterized as an associational attachment of a person to an object, be it a political leader, spouse, or a philosophical concept. Once formed, the attachment has the potential to distort perceptions and attitudes of a person in favor of the object of loyalty, effectively committing them to defending the interests of the object even if it involves costs or sacrifices. Various loyalties can come into conflict, which forces the person to make difficult choices, especially when some loyalties are irreconcilable. Usually, loyalty can be considered to include also an emotional component, which strengthens the primary bond. ${ }^{1}$

6 Political loyalty is specific as it includes also the aspect of political power, namely the power of the object of loyalty over the loyal subject. The modern bureaucratic state actively encouraged political loyalty through education or public ceremonies, as loyalty to the state made implementation of laws and directives easier and helped to prevent major disobedience. More relevant for the following discussion on immigration and loyalty, the modern state at the same time became suspicious of persons whose political loyalty was not so clear, be it for ethnic, religious, or political reasons. This mistrust often developed into forms of discrimination, as those deemed potentially disloyal could not be really trusted by the state and thus became de-facto second-class citizens. $^{2}$

7 The emotional part of the concept of loyalty is something of a problem. Even if people acted with all due deference and obedience towards state laws and authorities, they could still be accused of disloyalty. Doubts about their emotional commitment could not be easily dispelled, as potential traitors were believed to hide carefully their true loyalty beneath the formally obedient facade. ${ }^{3}$

8 The military draft highlights the aspect of power inherent in the notion of political loyalty. The state was able to make men willingly perform acts that most of them would otherwise not consider or actually even oppose by exploiting the notion of loyalty. The draft is illustrative also of the different components of political loyalty - some understand it as primarily complying with binding formal norms (I have to go to the army because it is the law), while others emphasize the emotional component (I want to go to the army to serve the object of loyalty). In cases of disloyalty, desertion can become a major problem, unless mechanisms for enforcing formal obedience are sufficiently strengthened.

9 Political loyalty can thus be understood as an attachment towards a political entity or regime, which enables both the formation of a polity and provides an important prerequisite for willing obedience to the norms formed by such a political entity. States 
are in general sensitive to any signs of disloyalty, as it implies a waning of state control and an increased need to rely on a more vigorous enforcement of formal rules. Immigrants, whose political loyalty often undergoes a transition from their homeland to the host country, are in this respect vulnerable to criticism by groups of native residents, who see their attachment as lacking.

3. Loyalty concerns and immigration in the U.S. context

In the U.S. context, it is important to note that political disloyalty to the British Crown was at the heart of the revolution which led to the foundation of United States. The disobedient revolutionaries broke their ties and bonds with the King and defeated the Loyalists, who were not willing to do so. Since then, the new country has promoted political loyalty among its inhabitants to replace any allegiances to other, potentially hostile political entities. ${ }^{4}$

11 For immigrants who fled adverse political conditions or outright persecution in Europe, it was not so difficult to respect the more relaxed U.S. laws and regulations. Political loyalty developed over time, especially in cases when the immigrants had made the decision to stay in the United States. For those who came to the U.S. only in pursuit of economic opportunities, the acquisition of a new political loyalty was more complicated, especially if they planned to return to their country of origin in the future. ${ }^{5}$ In times of crisis, ties to the new country had to be forged quickly. During the Civil War, able-bodied immigrants were sent to the front as Union soldiers straight from embarking in the U.S. ${ }^{6}$

Concerns about the lack of political loyalty of newcomers have been raised with varying strength by some in the native-born population ever since the United States became an independent country. They gave rise to the Nativist movement, which in a broader sense continues to this day, again with varying degrees of political salience. Nativists wanted to limit immigration to the U.S., and the issue of lacking political loyalty to the United States became one of their important arguments. ${ }^{7}$ Throughout the nineteenth century, the principal targets were Catholics and Chinese. Presumed loyalty to the Pope, which might be stronger than loyalty to the United States, became one of the issues that led Nativist advocates to formulate ludicrous conspiracy theories. The election campaigns of Catholics Al Smith and John F. Kennedy still had to address this issue deep into the twentieth century. ${ }^{8}$

13 Racism played the most important part in the restriction of Chinese immigration, but loyalty concerns were raised as well. The clustered nature of settlement, different cultural norms and incomprehensible language of the Chinese engendered fears of potential disloyalty or outright treachery behind appearances of being law-abiding. ${ }^{9}$

Around the turn of the nineteenth century, the most problematic aspect in connection to the political loyalty of immigrants from the Nativist standpoint became the radical leftist political orientation of some of the newcomers. Anarchists from Southeastern Europe demonstrated a disregard for U.S. laws allegedly favoring the capitalist class and showed little or no attachment to the United States political regime. The controversial execution of immigrant anarchists Nicola Sacco and Bartolomeo Vanzetti after a prejudiced trial in 1927 became a symbol of forceful preemptive action by the establishment against potentially disloyal immigrants. ${ }^{10}$ Already in 1924, the National Origins Act drastically reduced immigration. Loyalty concerns played an important role in the arguments in favor of the restrictive legislation. ${ }^{11}$ 
The Pledge of Allegiance is a relevant cultural product in this respect. Devised in 1890 , its use spread rapidly and was made mandatory in public schools by Congress in $1942 .{ }^{12}$ The notorious wording "I pledge allegiance to the Flag of the United States of America, and to the Republic for which it stands, one Nation under God, indivisible, with liberty and justice for all" includes the duty of obedience to political authorities. Frequent public reciting was, as with a mantra, meant to influence the emotional side as well.

From the standpoint of U.S. governments, loyalty became a critical concern especially during wars. The 1917 Espionage Act and 1918 Sedition Act curtailed freedom of speech and, for example, prevented both Socialist and German-American publications from being mailed to subscribers. Disloyalty became an offense punishable by 20 years in prison. ${ }^{13}$ During World War II, immigrants from Japan and their children became the primary suspects for potential disloyalty in the atmosphere of fear following the Pearl Harbor attack. Both immigrants born in Japan (the Issei) and children of immigrants from Japan (the Nisei) were affected by an executive order sending them to detention camps. The policy was even upheld by the U.S. Supreme Court in the notorious case of Korematsu v. the United States. ${ }^{14}$ The treatment of Japanese-Americans demonstrated the precarious position of immigrants, whose loyalty is automatically questioned in the receiving country. The exemplary record of the 442nd regiment fighting in Europe, which was composed mainly of Japanese-Americans, was partly a response to this overreaction on the part of the U.S. authorities. ${ }^{15}$

During the Cold War, national security trumped other concerns, and some groups of immigrants were even welcomed for their anti-communist credentials. Apart from fear of covert spying by agents, political loyalty did not become an issue, especially if the immigrants followed the strict anti-communist line in vogue at the time. ${ }^{16}$

In general, loyalty concerns in connection with immigration surfaced primarily for two reasons. Firstly, periods of increased immigration of people from different cultural and political backgrounds caused Nativists to perceive the newcomers as a threat to the prevalent institutional and political order. Secondly, immigrant groups from countries hostile to the U.S. were suspected of subjectively preferring their home countries and thus being potentially disloyal. Despite these two fears, various immigration waves proved to be quite obedient with respect to the political system and, in time, even loyal to the new country. In fact, the ability of the political system to incorporate newcomers became one of the attractions of the U.S. for the outside world.

4. Case study: Loyalty concerns related to immigrants from Mexico4.1 Allegations of disloyalty

High levels of immigration from Mexico have been criticized from a number of viewpoints - immigrants allegedly steal jobs from natives, cause wages to stay low, are a drain on public resources, commit crimes or subvert U.S. values. ${ }^{17}$ Yet all these claims are disputed on the academic level as well as within the public discourse. In this article I review the available literature and data and focus primarily on the perceived lack of loyalty of Mexican immigrants and their children, which is one of the arguments put forward by critics. ${ }^{18}$ As political loyalty has great symbolic value in the U.S., this argument is quite powerful - the vision of millions of disloyal inhabitants inside one's country is frightening for many U.S. citizens.

The accusations of potential disloyalty are coming primarily from what I call presentday Nativists. The group is quite diverse and includes politicians, academics as well as NGOs. ${ }^{19}$ The key unifying message is a drastic reduction of immigration, especially from 
Hispanic countries, and protection of the white Anglo-Saxon dominant ethos in politics and culture. ${ }^{20}$ The implication that the immigrant Latinos are "Other" and do not belong to the U.S. body politic is never far behind, ${ }^{21}$ effectively questioning their loyalty or even denying the very possibility that the immigrants could feel such an emotion.

On the political side, the Nativists are represented by Pat Buchanan, who almost won the Republican party nomination for the presidential elections of 1996 . To this day, he is an influential commentator in conservative media. In his 2006 book titled State of Emergency: The Third World Invasion and Conquest of America he explicitly warns that the U.S. Southwest might become another Kosovo because of the presence of MexicanAmericans (Chapter 8 of the book has the title "The Aztlan Plot"). ${ }^{22}$ Buchanan's sharp anti-immigrant political standard was carried in the 2008 presidential elections by Representative Tom Tancredo (R-Colorado) in his unsuccessful bid for the Republican party nomination. Other prominent Nativist politicians include Representative James Sensenbrenner (R-Wisconsin), author of a highly restrictive 2006 anti-immigration proposal.

In the media, radical Nativist sentiments are presented by prominent conservative commentators like Rush Limbaugh and Ann Coulter. ${ }^{23}$ Rush Limbaugh came up with his own Limbaugh laws on immigration:

You're allowed no demonstrations, you cannot wave a foreign flag, no political organizing, no bad-mouthing our President or his policies, or you get sent home. You're a foreigner. You shut your mouth or you get out, and if you come here illegally, you go straight to jail and we're going to hunt you down 'til we find you. ${ }^{24}$

The discourse is dehumanizing the immigrants to such an extent that it makes it difficult to even imagine the immigrants as having any loyalty towards the U.S. Still, the emphasis on political control and obedience betrays the hidden fears of potential disloyalty. On the Internet, an active and popular radical Nativist website is vdare.com, where illegal immigrants are demonized quite explicitly. ${ }^{25}$ Among the Nativist NGOs, The Minuteman project is perhaps the most radical, as it organizes armed vigilante patrols on the border who are rounding up illegal border-crossers. ${ }^{26}$ Within U.S. academic circles, the late Samuel Huntington was the most prominent sophisticated Nativist. In his article entitled 'Hispanic Challenge' he explicitly states his basic premise:

The persistent inflow of Hispanic immigrants threatens to divide the United States into two peoples, two cultures, and two languages. Unlike past immigrant groups, Mexicans and other Latinos have not assimilated into mainstream U.S. culture, forming instead their own political and linguistic enclaves-from Los Angeles to Miami-and rejecting the Anglo-Protestant values that built the American dream. The United States ignores this challenge at its peril. ${ }^{27}$

Even though he focuses primarily on the cultural clash, loyalty concerns are not far behind when he emphasizes the regional concentration of the "challenge". In his book Who Are We? he explicitly mentioned the Hispanization of the U.S. Southwest as a potential threat, effectively questioning the loyalty of Mexican-Americans. ${ }^{28}$

Immigrants from China have also face disloyalty charges based on their connection with the Communist motherland even though their socio-economic profile is quite different. ${ }^{29}$ Nevertheless, there are several factors that make loyalty concerns salient in the case of Mexican immigrants. First of all, most of the Mexican-Americans are concentrated in the region which once belonged to Mexico and which the U.S. acquired 
by conquest. Therefore, the increased migration is sometimes referred to as a sort of reconquista, alluding to the process in which Spaniards drove away the Moors from the Iberian Peninsula. This antagonizing parallel also implies less respect by immigrants for restrictive U.S. policies and enforcement agencies, which are in the long run seen as losing ground to the "reconquering" Mexicans. ${ }^{30}$

The historical memory of the humiliating Mexican-American war (called La invasión norteamericana in official Mexican textbooks) is kept fresh for Mexicans and MexicanAmericans in the Mexican media and popular culture. ${ }^{31}$ To add to this historic grievance, radical Mexican-American activists developed the concept of Aztlán, a supposed mythical homeland of the Aztec tribe located in the U.S. Southwest. The concept of Aztlán serves to highlight the connection of Mexicans to U.S. territory and, therefore, also their right to reside in it on an equal footing with other U.S. citizens even if they might have an illegal status in the eyes of the U.S. government. ${ }^{32}$ The widespread attention paid by the mainstream U.S. media to wild predictions made by Igor Panarin, who claimed that the U.S. would disintegrate by 2010 and parts of the Southwest would join Mexico, is indicative of the underlying loyalty fears that exist. ${ }^{33}$

Many U.S. Nativists are upset by the notion of Aztlán, as for them it threatens the political loyalty the Mexican immigrants and Mexican-Americans should feel towards the United States. Their fears relate to the possible annexation of the U.S. Southwest by Mexico, or the establishment of a hypothetical República del Norte which would join Northern Mexican and Southern U.S. states. ${ }^{34}$ Proponents of the concept of Aztlán, like the Movimiento Estudiantil Chicanos de Aztlán (MEChA) or the more radical Nation of Aztlán, focus on historical injustices and discrimination perpetrated by the U.S. government and the white majority, which serves to emotionally detach Mexican immigrants from official U.S. authorities and institutions. ${ }^{35}$ This only strengthens the suspicions of anti-immigrant and Nativist groups. MEChA has been accused of promoting separatism (which effectively means disloyalty) and racism on numerous occasions. $^{36}$

Sporting matches also highlight concerns about the loyalty of Mexican immigrants. When Mexican and U.S. teams meet on U.S. soil, Mexican-Americans and immigrants from Mexico overwhelmingly support the Mexican side, cheering and waving Mexican flags. After one soccer match in Los Angeles, the support for the Mexican team from the audience was so overwhelming that it led to complaints from the U.S. team in the media. The underlying concern was that the disloyalty the spectators demonstrated in the stadium was indicative of their more serious political disloyalty as well. ${ }^{37}$

Overwhelming displays of Mexican flags could also be seen at mass demonstrations organized throughout the U.S. in May 2006 by the Alianza Nacional para Derechos Humanos against the proposed law that would not only increase criminal penalties for illegal immigrants but also criminalize all those who help or assist them (such as religious charities). ${ }^{38}$ The fact that hundreds of thousands of illegal immigrants openly participated in the protests amounted to an open defiance of U.S. immigration laws, which further raised alarm in Nativist and anti-immigrant circles. The widespread presence of Mexican flags at the demonstrations suggested a breach of political loyalty, especially in the U.S. where the national flag serves as a key symbol of loyalty to the political system. ${ }^{39}$

30 Loyalty concerns with respect to immigrants from Mexico also increased because of a change in Mexican law in 1998, which for the first time allowed Mexican citizens to 
acquire dual citizenship. Before this reform, emigrants from Mexico who acquired U.S. citizenship automatically lost their Mexican one - the Mexican government was sensitive to the issue of potential double loyalties as well. The threat of a loss of Mexican citizenship was also the reason why many Mexican-Americans kept their Mexican permanent residency status and did not apply for U.S. citizenship even after spending many years in the U.S. (thereby only increased the suspicions of the Nativists). The policy reversal in Mexico was intended to promote ties of MexicanAmericans to Mexico; several million people are estimated to have acquired dual citizenship since then. ${ }^{40}$

31 On both the theoretical and symbolic levels, dual citizenship poses a problem, as countries are quite protective when it comes to the political loyalty of their citizens. In the event of a conflict between obligations owed to two states, it is not clear what the person with dual citizenship would do. ${ }^{41}$ On a practical level the dual citizen can choose which passport to present to the authorities, which usually makes bureaucratic life much easier for that person. On the symbolic level, however, dual citizenship is a sign that the attachment to either country is potentially compromised by other ties.

Furthermore, dual citizens are entitled to vote in both U.S. as well as Mexican elections. One person can thus develop political affiliations with two different parties and cast votes twice as often ${ }^{42}$ Recent changes in Mexican electoral law even allow for Mexican citizens residing in the U.S. to vote in Mexican elections at consulates throughout the U.S. Thus, U.S. permanent residents (who are not entitled to vote in the U.S.) and even illegal immigrants can influence the electoral process in Mexico, but not in the communities or states where they reside..$^{43}$ As political participation is usually positively correlated with loyalty to the political regime, the factual disenfranchisement of many immigrants from Mexico is a worrying signal with respect to their political loyalty to the U.S. The ultimate test of dual citizenship is of course if both countries should go to war, claiming the allegiance of the dual citizen from both sides. However, as military conflict between the U.S. and Mexico is not realistic today, this is unlikely to arise in this case.

More important are concerns about crime. Present-day Nativists often cite an increased propensity towards crime as the consequence of a decreased feeling of political loyalty. According to this logic, the fact that even legal immigrants do not feel sufficient loyalty to the U.S. political regime enables them to commit crimes and experience little or no remorse for their transgression of the law. ${ }^{44}$ As criminal law is the outcome of the political process within the U.S., the allegedly disloyal immigrants are supposed to break it more easily than loyal citizens.

Concerns about loyalty of illegal immigrants from Mexico are more acute, as their illegal status in the U.S. forces them outside any system of formal rules and procedures. Seen from the Nativist perspective, such people are already outlaws who are breaking the law by their very existence - they can hardly feel any attachment to a political system that criminalizes them. ${ }^{45}$ The fear of increased criminality serves as a powerful scare argument in U.S. politics in general. Attempts are thus made by Nativist politicians to connect the questionable loyalty of immigrants to the sense of danger the disloyal immigrants are supposed to represent. ${ }^{46}$ This leads us back to the crucial question: Are immigrants from Mexico really so disloyal?

4.2 Basic characteristics of immigrants from Mexico 

provide a review of their basic characteristics as an immigrant group in order to set the context. Approximately 43.4 million people residing in the U.S. consider themselves to be Hispanic or Latino, forming around 15 percent of the overall American population. From this number, 28.3 million (or 65.2 percent) would describe themselves as Mexican-Americans. Only 9.9 million (or 34.9 percent) of these Mexican-Americans were born in Mexico, that is, are first-generation immigrants. These figures, provided by the U.S. Census Bureau, include also those illegal immigrants from Mexico who were counted by the authorities. ${ }^{47}$ Researchers focusing on illegal immigrants estimate the illegal Mexican-born population to be around 7 million, out of an approximate total of 12 million illegal immigrants. ${ }^{48}$

fimportant fact that recent immigrants from Mexico are merely part of a much larger Mexican-American group, which is quite diverse with respect to the time they have spent in the United States and consequently also with respect to the attachment they feel to the country. In fact, ancestors of some MexicanAmericans were living on the land even before the U.S. acquired it in the aftermath of the Mexican-American War in 1848. As a result of this diversity within the group, there are varying degrees of assimilation and acculturation, which translates also into different political attitudes. Without making this critical distinction, analysts and commentators make the common mistake of focusing on recent immigrants and then extend their observations to Hispanics as a whole. ${ }^{49}$

A second analytically important feature of Mexican immigration is its regional concentration. Border states with Mexico as well as big cities like Chicago and New York have attracted a disproportionate amount of immigrants from Mexico. The population of Los Angeles consists of 46.5 percent Hispanics, most of them of Mexican origin, while Phoenix has about 41.5 percent. In recent years, Mexican immigrants started to disperse into other areas of the United States as well, but this did not change the regional aspect of their presence in the U.S. Even within cities, most immigrants from Mexico are usually clustered in specific neighborhoods (barrios)..$^{50}$ The territorial aspect is important, as it allows for analytical comparisons between regions with both a high and low Hispanic presence respectively.

38 A third important aspect is the dynamics of immigration flows from Mexico over time. Mexican migrant workers have been a continuous presence in the U.S. Southwest since the last half of the 19th century. Many of these workers were seasonal and returned to Mexico after the work (harvest) was done. Some stayed, gradually increasing the Mexican-American population in the country. During the Great Depression, the U.S. government organized mass deportations of persons of Mexican origin to free up jobs, which affected up to 2 million people, including many children born on U.S. soil who were thus formally U.S. citizens. ${ }^{51}$

As the economy recovered during World War II, so did the number of Mexican immigrants, many of whom were part of the official Bracero Program for guest workers. After the job market became tighter in the aftermath of the Korean War, another round of mass deportations called Operation Wetback occurred in 1954. This heavy-handed effort did not stem the tide either. The liberalization of immigration laws enacted in 1964 and Mexican economic difficulties starting in the 1970s resulted in an increasing number of both legal and illegal immigrants. ${ }^{52}$ 

networks ensured a steady flow of people over the border throughout the 1980s and 1990s, despite increasing resources being devoted to border protection by the U.S. Border Patrol. Economic integration under the North American Free trade Association (NAFTA) failed to generate enough jobs in Mexico to curb emigration. As a result, the Mexican economy became more and more dependent on remittances from emigrants, which peaked at 23 billion USD per year in $2006 .{ }^{53}$ The number of Mexicans apprehended at the border for attempting to cross illegally fell from the highest points of 2 million in 1998 to 858,638 in $2006 .{ }^{54}$ Yet even after this decline it still remains a staggering figure, emphasizing the massive migration flows that cross the border.

41 immigration flow. Economic indicators are also highly relevant for the attitude of the U.S. authorities, which are responsive to employer needs. The economic crisis starting in 2008 hit the sectors employing Mexican immigrants especially hard. This already led to a dramatic decrease in immigration from Mexico, and many recent immigrants opted to return home rather than be unemployed in the U.S. ${ }^{55}$

4.3 Measuring the Loyalty of Mexican Immigrants

As the previous section demonstrated, Mexican immigrants are part of a larger group of Mexican-Americans, forming a diverse body ranging from those fully assimilated to illegal immigrants who arrived only recently. It is to be expected, therefore, that loyalty will be perceived differently by different members of this group. This creates a methodological challenge, as some data is available only for Mexican-Americans or even Hispanics or Latinos as a whole. Analytically, foreign-born Mexican-Americans living in the United States are more relevant for the original research question. Data on the subgroup of illegal immigrants from Mexico are important, as we would expect the least amount of political loyalty in their case. With these distinctions in mind, we still need some way to measure or at least estimate the level of political loyalty felt towards the U.S.

One possible method of measuring political loyalty is by directly asking the relevant group. In particular, the Pew Hispanic Survey has conducted various in-depth studies on this and related issues, the results of which could be used. The answers confirm clearly that attachment to the U.S. (which is related to loyalty) grows with time spent in the country. Only one in ten Hispanic Americans keep very strong ties to their homeland, measured by proxy indicators such as sending remittances, phoning relatives frequently, and traveling to the country of origin. ${ }^{56}$ Signs of disloyalty with respect to the political system appear only in the case of harsh treatment and discrimination of immigrants by U.S. authorities, which the group considers mostly unjust and even illegitimate. ${ }^{57}$ On the other hand, Latinos as a whole were quite active in the 2008 presidential campaign, which is an indicator of political attachment to the country. For example, one in seven registered Latino voters contributed money to the campaign. ${ }^{58}$

Surveys also tell us that foreign-born Mexican-Americans are much less loyal culturally; they preserve strong ties to their language and customs, and through that also towards Mexico as their country of origin. There is, however, a clear distinction between loyalty in the cultural and political sense, as allegiance to Mexico as a political entity is rather low..$^{59}$ For that reason, the prospect of Mexican-Americans eagerly wishing to politically 'secede' from the U.S. to join Mexico is highly unrealistic. To add 
to this, an acceptance of selected aspects of U.S. cultural and social life like a suburban consumer lifestyle or hip-hop music among Hispanic youth is high, complementing but not replacing the attachment towards Mexican culture. ${ }^{60}$ In another survey, 63 percent of Latinos agreed that it would be very important for future generations of Latinos living in the United States to speak Spanish, which can signify both a reluctance to abandon Mexican culture and a realization that Spanish has such a strong presence in some parts of the U.S. that it would be a disadvantage not to speak it alongside English. 61

Apart from surveys, we can also estimate the level of loyalty by analyzing hard data on various proxy variables and indicators related to loyalty. For example, serving in the U.S. military can be considered as a sign of political loyalty, especially in a time of war when the risks of getting killed or injured are higher. Therefore, the number of Mexican immigrants enlisted is relevant. The available figures show that currently about 11.4 percent of enlisted active duty soldiers are of Hispanic origin, most of them presumably with roots in Mexico. In 1972, the same figure was only 3.4 percent, demonstrating a considerable increase. ${ }^{62}$ At the same time, only 5 percent of army officers are currently of Hispanic origin. As a disproportionate number of Hispanic recruits end up in the Marine Corps, they are also more likely to be assigned to frontline engagements. It is therefore not surprising that hundreds of soldiers of Hispanic origin have already lost their lives in operations in Iraq and Afghanistan. ${ }^{63}$ Many of them joined the U.S. military just to get funding for college or expedited citizenship. ${ }^{64}$ The participation of so many Hispanics (some of them foreign-born) in the armed forces is indicative of political loyalty towards the U.S., even though the reasons for joining the military are often related to other factors. ${ }^{65}$ The figures can perhaps be better used to refute allegations of disloyalty - if immigrants from Mexico would feel no attachment to the U.S., we should observe a greater reluctance towards voluntarily joining the military and thus potentially sacrificing one's life for the country.

Statistics available for the Border Patrol are also relevant, as one could expect Hispanic Americans to opt for other careers than to guard the border against other impoverished Hispanics who want to improve their lives in the U.S. Also, proimmigration activists cite the brutality of the Border Patrol agents as one of their main concerns. ${ }^{66}$ In fact, 52 percent of Border Patrol personnel are Hispanic. ${ }^{67}$ Several factors might cause this high figure, such as the proximity of the border to the areas of Hispanic-American concentration or the requirement for agents to speak Spanish, but it nonetheless implies considerable loyalty on the part of the agents to the U.S. regime as a whole. It also suggests that the "us versus them" concept on which the Nativist agenda hinges is inaccurate at best.

Another potential indicator of loyalty is the extent to which Mexican immigrants with permanent residency status apply for U.S. citizenship. For many years, migrants from Mexico were mostly content to acquire just permanent residency status and did not strive to become U.S. citizens. However, since the mid-1990s, citizenship applications from Mexican-Americans have kept rising, reaching 128,000 naturalizations of people of Mexican origin in 2007. ${ }^{68}$ Even though economic concerns, such as welfare reforms aimed to exclude non-citizens from receiving benefits, and the possibility of acquiring dual citizenship definitely played an important role in this upward trend, becoming a citizen is nevertheless a clear act confirming political loyalty to the country as a whole. 
Questions in the naturalization test specifically mention loyalty to the United States as one of the promises of the new citizen. ${ }^{69}$ The ancient institute of oral promise aims to strengthen emotional ties, but also includes the moral aspect of keeping the promise in case the emotional component is missing. The naturalization ceremony is in fact an elaborate modern ritual, where the new subjects swear allegiance (and loyalty and obedience) to the new country (and thus political master). ${ }^{70}$

Data on crime among foreign-born Mexican-Americans should be examined, in order to test the Nativist thesis that alleged diminished loyalty leads to a greater propensity to commit crime. We know that Hispanics in general have higher incarceration rates than non-Hispanic whites. Some Nativists thus cling to the essentially racist argument that more Hispanics in the U.S. automatically translates into an increased crime rate. ${ }^{71}$ However, they fail to acknowledge that, throughout the 1990s, when the numbers of new immigrants from Mexico (many of them illegal) rose dramatically, crime rates actually fell throughout the United States. Moreover, African Americans have even higher incarceration rates than Hispanics do. ${ }^{72}$

Even studies by the Center for Immigration Studies, which is advocating for more restrictions on immigration, had to admit that immigrants do not commit more crimes than the rest of the population. ${ }^{73}$ Furthermore, not even illegal immigrants, who are by definition outside the law, commit violent crimes at a higher rate than other marginalized groups. ${ }^{74}$ Other detailed studies found that crime rates among recent immigrants are actually much lower than among native-born citizens. ${ }^{75}$ The thesis that foreign-born disloyal immigrants commit more crimes than native-born citizens is thus not based on any relevant evidence. Nativist advocates therefore resort to highlighting prominent cases where an illegal immigrant is the perpetrator, thus sidelining the statistical evidence. ${ }^{76}$ The image of a dehumanized illegal "alien" criminal feeling no loyalty to U.S. institutions or the American people thus keeps plaguing the immigration discourse.

To uphold the claim that illegal immigrants are more likely to commit crimes, one would have to include the forging of documents needed for gaining employment. Yet this is an unfair argument in the sense that it is connected to their status as illegals in the first place, and it does not in any way reflect actions or attitudes of the alleged "criminals". ${ }^{77}$

51 Further evidence supports the view that immigrants from Mexico are, by and large, loyal to U.S. institutions and the political system as a whole. Massive demonstrations in May 2006 against restrictive immigration legislation, in which many immigrants took part, were peaceful and non-violent even though they were supposed to convey a strong political message and numerous illegal immigrants openly participated in the protests as well. During the 1992 L.A. riots, immigrants from Mexico were more often targets than participants in mob violence. Chicano radical nationalist groups modeled after the Black Panthers (like the Brown Berets) were active in the late 1960s and early 1970s, but since then most political activism is far less extreme and focused primarily on better conditions in local communities or the general advance of Hispanics in U.S. society. ${ }^{78}$ Apart from fringe figures or hardened criminals, it would be hard to find immigrants from Mexico who could be considered truly disloyal to the fundamentals of the U.S. political system in the sense of deliberately disregarding public order, even though their ties to the country are still limited. 
52 After examining several proxy measures of political loyalty of Mexican immigrants, we can conclude that in many respects it is surprisingly high given the allegations of disloyalty described above. How can we explain this apparent paradox and what can we learn from it?

5. Conclusion: Loyalty Concerns and Immigration

53 As waves of immigrants continued to arrive in the U.S. in the nineteenth century, a political loyalty to the new country, in the sense of obedience to the established public order, was sufficient for social acceptance if not necessarily equal social status. Even though Nativism has always been present, as long as newcomers proved loyal to the U.S. it had only a limited impact on the enactment of restrictive immigration policies. As long as the immigrant demonstrated enough deference to political authority and accepted the political system, he or she could preserve his or her customs and habits. Over time, ties to the new country evolved into loyalty as well as acceptance of U.S. mainstream culture and language, giving rise to the melting pot metaphor. This open model, based on the primacy of the political process over divisive cultural or national backgrounds, proved to be successful as it allowed for the inclusion of diverse groups. The case of exclusion of migrants from China, however, demonstrated that cultural and ethnic prejudice could override the emphasis on political loyalty as a precondition for acceptance.

54 Current concerns about immigrants from Mexico demonstrate that the immigration model based on the primacy of political loyalty is under threat. By many standards, the immigrants are quite loyal especially in the sense of respecting the political order, and yet they still become targets of modern-day Nativist suspicion or even wrath. ${ }^{79}$ This can be explained by looking closer at the concept of loyalty itself. From the Nativist point of view, the immigrants from Mexico represent not a political, but rather a cultural threat. Their perceived lack of loyalty is not to the political institutions, but to the predominant U.S. cultural model as the Nativists imagine it (based on an AngloSaxon identity, the English language, individualism, rationality, and self-reliance). The persisting cultural loyalty (meaning in this case primarily emotional ties) of Mexican immigrants towards Mexico explains the Mexican flags at sporting events, which so disturb some of the Nativists. ${ }^{80}$ These expressions of cultural affinity are not necessarily in any way connected to political loyalty, but can be easily misinterpreted as such by outside observers. ${ }^{81}$

Apart from cultural concerns, the accusations of potential disloyalty against Mexican immigrants are also driven by the notions of obedience and power implicitly inherent in the concept of loyalty. As long as immigrants remain complacent, accepting the social status designed for them by the majority, the issue of loyalty does not arise. However, once they start demanding rights, they may easily be cast as ungrateful troublemakers disloyal to the generous accepting country. This notion is based on the flawed assumption that political loyalty should be based on unquestioning obedience to the authorities currently in power. However, forced loyalty oaths at universities in the 1950s or frequent accusations of disloyalty against civil rights leaders like Marin Luther King demonstrated that the concept could too easily be employed to suppress unwelcome statements. As conceptualized by Hirschman, the protesting immigrants might be just exercising the "voice" option, which can be consistent with the notion of loyalty. ${ }^{82}$ 
The discursive use of Aztlán and Mexican flags in political demonstrations against harsh anti-immigrant legislation should be viewed within this context as well. These are indeed meant to bring attention to the fact that Mexican immigrants have been part of the territory now under U.S. jurisdiction. However, the symbolism is applied defensively as a reaction to stricter measures pushed by Nativists and their political allies. ${ }^{83}$ It does not imply any active effort to disrupt the territorial integrity of the United States, nor to engage in other acts of disloyalty to the country.

This defensive attitude is driven by the fact that many Mexican immigrants are nowadays formally in the position of second- or third-class citizens with very little in the way of legal protection, even though they have been living in the country for years, making an honest living for very low pay. ${ }^{84}$ Even though political participation and representation is increasing, Mexican immigrants are still in an asymmetric position with respect to the rest of the population. Restrictive legislation like the Secure Fence Act of 2006, which mandated the construction of hi-tech fence on the U.S.-Mexican border has been passed at the federal level despite widespread vocal opposition from the Mexican-American community. ${ }^{85}$

5 We can thus observe in the case of immigrants from Mexico that political loyalty understood as a respect for basic principles and institutions of the government is not sufficient for present-day Nativists within the U.S. Additional demands for both cultural loyalty and obedience get included as well. This development undermines the idea of the assimilation process, according to which anybody could come to the U.S., and as long as he or she remained loyal to the country, he or she would sooner or later become accepted into its diverse community.

The case of immigrants from Mexico, who to some extent remain culturally loyal to Mexico and who are at the same time politically loyal residents of the U.S., raises some important theoretical questions with respect to the concept of loyalty and relations between individuals and the state in general.

60 Firstly, how should we interpret the concept of political loyalty in times of massive trans-border population movements? As long as expansive notions of loyalty, including also cultural and emotional affinity and unquestioning obedience, are demanded as well, they are bound to antagonize the significant immigrant population that would be unable to comply. Respect for constitutional order and institutions such as that demonstrated by most immigrants from Mexico should be sufficient to dispel allegations of disloyalty to the country. The fact that a person has ties to two countries does not disqualify him or her from meaningful political participation in either country. On the contrary, such people might play a positive role in fostering valuable trans-border cooperation.

Secondly, how should the state treat illegal immigrants who are quite loyal to the political and social order (even if they do so only to avoid any trouble with authorities)? The repressive attitude of the state can undermine the loyal behavior of these residents and disrupt them from developing positive attitudes towards the country. Especially with long-term illegal immigrants, who are politically loyal to the country, the state should at least recognize this loyalty and show basic respect for these individuals in return. The concept of political loyalty could thus be expanded to include a mutually reinforcing obligation between the resident and the state. Otherwise, the state unnecessarily antagonizes people who are inclined to respect it, in doing so risking losing their loyalty (the "exit" option formulated by Hirschman). ${ }^{86}$ 
Reconsidering political loyalty so that it becomes more limited in its demands and more reciprocal in its scope would be beneficial not only for immigrants and their acceptance and subsequent integration into the host society. All persons engaged in transnational activities could benefit as a result of more relaxed and less exclusive demands for political loyalty. Confrontational or discriminatory practices using potential disloyalty or outright fear of the "Other" as their rationale only increase trans-border tensions and hamper the process of immigrant integration. The case of Mexican immigrants, who maintain close ties to their country of origin and its culture and, at the same time, show clear signs of loyalty to the United States, demonstrates that mass immigration does not have to be a major threat to the fundamental political processes and institutions in the host country.

Krystof Kozak, Department of American Studies, Institute for International Studies, Charles University, Prague

\section{NOTES}

*. This study was supported by Research Objective MSM0021620841 of the Czech Ministry of Education. The author would like to thank Dr. Giles Scott-Smith and anonymous EJAS reviewers for helpful comments and suggestions on earlier drafts of the paper.

1. John Kleinig, "Loyalty", Stanford Encyclopedia of Philosophy, first published August 21, 2007, available at: http://plato.stanford.edu/entries/loyalty/ (accessed March 3, 2009).

2. Yossi Shain, The Frontier of Loyalty: Political Exiles in the Age of the Nation-State

(University of Michigan Press, 2005), 20.

3. Judith N. Shklar, "Obligation, Loyalty, Exile," Political Theory, Vol. 21, No. 2, 1993: 181-197.

4. Merill Jensen, The New Nation: A History of the United States during the Confederation, 1781-1789, (New York: Vintage Books, 1950), 90-98, 265-282.

5. Oscar Handlin, The Uprooted, (Boston: Little, Brown \& Company, 1973, Second Edition) 85-104, 231-254.

6. Adam Smith, The American Civil War, (New York: Palgrave Macmillan, 2007), 178-189.

7. Bruce Levine, "Conservatism, Nativism, and Slavery: Thomas R. Whitney and the Origins of the Know-Nothing Party," The Journal of American History, Vol. 88, No. 2 (Sep., 2001), 455-488; Raymond L. Cohn, "Nativism and the End of the Mass Migration of the 1840s and 1850s," The Journal of Economic History, Vol. 60, No. 2 (Jun., 2000), 361-383.

8. James H. Smylie, "The Roman Catholic Church, the State and Al Smith," Church History, Vol. 29, No. 3 (Sep., 1960), 321-343; transcript of John F. Kennedy's address to the Greater Houston Ministerial Association on the issue of religion from September 12, 1960 is available online at National Public Radio, http://www.npr.org/templates/story/ story.php?storyId=16920600 (accessed March 3, 2009).

9. For an example of the prevalent discourse at the time, see Thomas Magee, Chinese Menace to the World, Knights of Labor, 1878, now available at: http:// www.sfmuseum.net/loc/magee.html (accessed March 3, 2009. 
10. Phillip V. Cannistraro, "Mussolini, Sacco-Vanzetti, and the Anarchists: The Transatlantic Context," The Journal of Modern History, Vol. 68, No. 1 (Mar., 1996), 31-62. 11. David H. Reimers, "History of Recent Immigration Regulation," Proceedings of the American Philosophical Society, Vol. 136, No.2, (1992), 176-187.

12. Title 4, Chapter $1, \S 4$ of the U.S. Code, available at: http://www4.law.cornell.edu/ uscode/html/uscode04/usc_sec_04_00000004----000-.html (accessed March 3, 2009). 13. Geoffrey R. Stone, Perilous Times: Free Speech in Wartime: From the Sedition Act of 1798 to the War on Terrorism (New York: W.W.Norton, 2005), 187.

14. Korematsu v. United States, 323 U.S. 214, full text of the decision available at: http://www.law.cornell.edu/supct/html/historics/USSC_CR_0323_0214_ZD2.html (accessed March 3, 2009).

15. See, for example, Global Security, 100th Battalion, 442nd Infantry, available at: http:// www.globalsecurity.org/military/agency/army/100-442in.htm (accessed March 3, 2009).

16. Carl J. Bon Tempo, Americans at the Gate: The United States and Refugees during the Cold War, (Princeton: Princeton University Press, 2008), 113.

17. For a list of anti-immigration grievances, see for example the website of the Federation for American Immigration Reform (FAIR) "Immigration Issues", available at: http://www.fairus.org/site/PageNavigator/issues/ (accessed March 3, 2009).

18. See Christopher G. Adamo, "Foreign Collaborators Of The American 'Insurgency'," The Progressive Conservative, USA, Volume IX, Issue 141, (July 25, 2007) or Jon E. Dougherty, Illegals: The Imminent Threat Posed By Our Unsecured U.S.-Mexican Border (Nashville: WND Books, 2004).

19. Brian N. Fry, Nativism and Immigration: Regulating the American Dream, (LFB Scholarly Publishing, 2006), 35.

20. Vilho Harle, The Enemy with a Thousand Faces. The Tradition of the Other in Western Political Thought and History, (Praeger, Westport, Conn., 2000).

21. David C. Brotherton and Philip Kretsedemas (eds.), Keeping Out the Other. A Critical Introduction to Immigration Enforcement Today (Columbia University Press, 2008), 5.

22. Pat Buchanan, State of Emergency: The Third World Invasion and Conquest of America, Thomas Dunne Books, 2006, 12.

23. See for example Ann Coulter: "It depends what the meaning of the word 'deficit' is," Townhall.com, August 23, 2003, http://townhall.com/columnists/AnnCoulter/ 2003/08/21/it_depends_what_the_meaning_of_the_word_deficit_is?page=2 (accessed October 1, 2009).

24. Transcript of Rush Limbaugh radio show, April 6, 2006, available at: http:// www.rushlimbaugh.com/home/daily/site_091708/content/ The_Limbaugh_Laws.guest.html (accessed October 1, 2009).

25. Brenda Walker: California Nightmaring, With Mass Immigration A Key Demon, vdare.com, September 27, 2009, available at: http://www.vdare.com/walker/ 090930_california.htm

26. The website of the The Minuteman Project is available at http:// www.minutemanproject.com (accessed September 24 2009).

27. Samuel Huntington: "The Hispanic Challenge", Foreign Policy, March/April 2004.

28. Samuel Huntington: Who Are We: The Challenges to America's National Identity, (Simon \& Schuster, 2005), 252. 
29. Brenda Walker, Mentioning The Unmentionable About The Chinese "Model Minority", October 17, 2007, available at: http://www.vdare.com/walker/071017_chinese.htm (accessed September 24 2009).

30. Tania Molina Ramirez: "Los migrantes expresan en la música el temor de EU a la reconquista", La Jornada, October 15, 2006.

31. Dennis Gilbert: "Rewriting History: Salinas, Zedillo and the 1992 Textbook Controversy", Mexican Studies / Estudios Mexicanos, Vol. 13, No. 2, (Summer, 1997), 276. 32. Full text of the "Plan Espiritual de Aztlán" formulated at the First National Chicano Liberation Youth Conference in March 1968 is available at: http:// carbon.cudenver.edu/MEChA/plan-aztlan.html (accessed March 3, 2009).

33. Andrew Osborn, “As if Things Weren't Bad Enough, Russian Professor Predicts End of U.S., “ Wall Street Journal, December 29, 2008.

34. Explore for example the explicit anti-immigant website http:// www.illegalaliens.us/aztlan.htm (accessed March 3, 2009).

35. See Armando Navarro: Mexicano political experience in occupied Aztlán. Struggles and Change, (Altamira Press, 2005).

36. Matt Hayes, "Bustamante Silent on Separatist Past," FoxNews, September 4, 2003, available at: http://www.foxnews.com/story/0,2933,96371,00.html (accessed March 3, 2009).

37. Gregory Rodriguez, "Don't Equate Rudeness With Disloyalty," The Los Angeles Times, February 20, 1998.

38. Full text of the restrictive legislation (H.R.4437) proposed by Rep. James Sensenbrenner is available at: http://thomas.loc.gov/cgi-bin/bdquery/z?d109:H.R.4437 (accessed March 3, 2009).

39. Charles Krauthammer, "Immigrants Must Choose," The Washington Post, April 14, 2006.

40. Jeffrey K. Staton, Robert A. Jackson and Damarys Canachea, "Dual Nationality Among Latinos: What Are the Implications for Political Connectedness?" The Journal of Politics, Vol. 69, No. 2 (May 2007), 470-482.

41. Stanley Renshon, "Dual Nationality + Multiple Loyalties = One America?" In Stanley Renshon (ed.), One America? Political Leadership, National Identity, and the Dilemmas of Diversity, (Washington, D.C: Georgetown University Press), 232-82.

42. Jack Kelly, "Number of dual citizens in U.S. soaring," Pittsburg Post-Gazette, May 15, 2002, available at: http://www.post-gazette.com/nation/20020515dual0515p4.asp (accessed March 3, 2009).

43. Instituto Federal Electoral, "Voto en el Exterior," available at: http:// www.ife.org.mx/documentos/votoextranjero/voto_legislacion.htm (accessed March 3, 2009).

44. Carl F. Horowitz, An Examination of U.S. Immigration Policy and Serious Crime, Center for Immigration Studies, April 2001, available at: http://www.cis.org/articles/2001/ crime/toc.html (accessed March 3, 2009).

45. Jon E. Dougherty, Illegals: The Imminent Threat Posed By Our Unsecured U.S.-Mexican Border (Nashville: WND Books, 2004).

46. Maggie Ibrahim, "The Securitization of Migration: A Racial Discourse," International Migration, Vol. 43 No. 5, (2005), 163-187.

47. U.S. Census Bureau, The Hispanic Population. Census 2000 Brief, available at: http:// www.census.gov/population/www/cen2000/briefs/index.html (accessed March 3, 2009). 
48. Jeffrey S. Passel, Size and Characteristics of the Unauthorized Migrant Population in the U.S., Pew Hispanic Center, 3 June 2006, available at: http://pewhispanic.org/reports/ report.php?ReportID=61 (accessed March 3, 2009).

49. Huntington, "The Hispanic Challenge," Foreign Policy, March/April 2004.

50. Daniel Dohan, The Price of Poverty. Money, Work and Culture in the Mexican American Barrio, (Berkeley: University of California Press, 2003), 10-15.

51. Juan Gonzalez, Harvest of Empire: A History of Latinos in America, (Penguin, 2001), 106.

52. Ellwyn R. Stoddard, "A Conceptual Analysis of the 'Alien Invasion': Institutionalized Support of Illegal Mexican Aliens in the U.S.," International Migration Review, Vol. 10 No. 2., (1976), 157-189.

53. Jesus Cañas, Roberto Coronado and Pia M. Orrenius, "Explaining the Increase in Remittances to Mexico," Southwest Economy, Federal Reserve Bank of Dallas, Issue 4, (July/August 2007).

54. Richard Marosi, "Apprehensions of border-crossers drop," The Los Angeles Times, November 7, 2007.

55. Ávila, Oscar, "Mexican immigrants moving back home amid sour economy", Chicago Tribune, December 24, 2008.

56. Roger Waldinger, Between Here and There: How Attached Are Latino Immigrants to Their Native Country?, Pew Hispanic Center Report No.80, October 25, 2007, 27, available at: http://pewhispanic.org/files/reports/80.pdf (accessed March 3, 2009).

57. 2007 National Survey of Latinos: As Illegal Immigration Issue Heats Up, Hispanics Feel a Chill, Pew Hispanic Center Report No.83, December 13, 2007, 31, available at: http:// pewhispanic.org/files/reports/83.pdf, (accessed March 3, 2009).

58. Mark Hugo Lopez, Susan Minushkin, 2008 National Survey of Latinos: Hispanic Voter Attitudes, Pew Hispanic Center Report No.90, July 24, 2008, 5, available at: http:// pewhispanic.org/files/reports/90.pdf (accessed March 3, 2009).

59. David G. Gutierrez, "Migration, Emergent Ethnicity, and the 'Third Space': The Shifting Politics of Nationalism in Greater Mexico," The Journal of American History, Vol. 86, No. 2, (September 1999), 481-517.

60. Geoffrey Fox, Hispanic Nation: Culture, Politics and the Constructing of Identity (Secaucus, NJ: Birch Lane Press Book, 1996), 228.

61. Pew Hispanic Center/Kaiser Family Foundation: 2004 National Survey of Latinos, Politics and Civic Participation, 74, available at: http://pewhispanic.org/files/reports/ 33.pdf (accessed March 3, 2009).

62. U.S. Army: "Hispanic Americans," available at: http://www.army.mil/ hispanicamericans/english/about/statistics.html (accessed March 3, 2009).

63. "Latino Soldiers Lead in Iraq Deaths Among Soldiers of Color," El Tiempo Latino, March 23, 2007, Megan Feldman, "Yo Soy el Army. Uncle Sam wants you--especially if you're Latino," The Dallas Observer, February 8, 2007.

64. Betsy Streisand, "Latin Heroes. Hispanics have been joining up in record numbers. But no one planned on dying," U.S. News \& World Report, April 4, 2003; Laura Barker and Jeanne Batalova, The Foreign Born in the Armed Services, Migration Policy Institute, January 2007, available at: http://www.migrationinformation.org/Usfocus/ display.cfm?ID=572 (accessed March 3, 2009).

65. Refugio I. Rochin and Lionel Fernandez, U.S. Latino Patriots: From the American Revolution to Afghanistan, An Overview, Pew Hispanic Center Report, available online at: http://pewhispanic.org/files/reports/17.3.pdf (accessed March 3, 2009). 
66. Justin Akers Chacón, Mike Davis: No One Is Illegal, (Haymarket Books, Chicago, 2006), 203.

67. U.S. Customs and Border Patrol: "CBP Meets 18,000 Border Patrol Agent Hiring Commitment - Weeks Early," December 17, 2008, available at: http://www.cbp.gov/ xp/cgov/newsroom/news_releases/archives/2008_news_releases/ december_2008/12172008_9.xml (accessed September 15, 2009).

68. Department of Homeland Security, 2007 Yearbook of Immigration Statistics, available at: http://www.dhs.gov/ximgtn/statistics/publications/yearbook.shtm (accessed March 3, 2009).

69. The sample tests are at the United States Citizenship and Immigration Services website at: http://www.uscis.gov/newtest (accessed March 3, 2009).

70. Susan Bibler Coutin: Cultural Logics of Belonging and Movement. Transnationalism, Naturalization and U.S. Immigration Policies, American Ethnologist, Vol. 30, No. 4 (Nov., 2003), 516.

71. Cf. Steve Sailer, "Mapping The Unmentionable: Race And Crime," February 23, 2005, available at: http://vdare.com/sailer/050213_mapping.htm (accessed March 3, 2009).

72. Heather C. West and William J. Sabol, "Prisoners in 2007," Bulletin of Justice Statistics, December 2008.

73. Carl F. Horowitz, An Examination of U.S. Immigration Policy and Serious Crime, Center for Immigration Studies, April 2001, available at http://www.cis.org/articles/2001/ crime/toc.html (accessed March 3, 2009).

74. Rubén G. Rumbaut and Walter A. Ewing, The Myth of Immigrant Criminality and the Paradox of Assimilation: Incarceration Rates among Native and Foreign-Born Men, Immigration Policy Center Special Report, available at: http:// ww.immigrationpolicy.org/index.php?content=sr20070221 (accessed March 3, 2009). 75. Kristin F. Butcher and Anne Morrison Piehl, Crime, Corrections, and California: What Does Immigration Have to Do with It? Public Policy Institute of California, February 2008, available at: http://www.ppic.org/main/publication.asp?i=776 (accessed March 9, 2009).

76. For example, see the website of Victims of Illegal Alien Crime at: http:// www.voiac.org/ (accessed March 9, 2009).

77. Leo R. Chavez, "Immigration Reform. The Nationalist Response to Transnational Challenge," in Juan Perea (ed.), Immigrants Out!: The New Nativism and the Anti-Immigrant Impulse in the United States, (NYU Press, 1996), 63.

78. Roberto Suro, Strangers Among Us: Latino Lives in a Changing America, (New York: Vintage, 1999).

79. For an example of intense prejudices, see the discussion in a hoax article claiming that MEChA activists deliberately started fires in California: http://www.topix.com/ forum/news/immigration/TCNAC75FB92PMH4C4 (accessed March 3, 2009).

80. for the concept of cultural loyalty, see James Connor: The Sociology of Loyalty, Springer, 2007, 117.

81. David G. Gutierrez, "Migration, Emergent Ethnicity, and the 'Third Space': The Shifting Politics of Nationalism in Greater Mexico," The Journal of American History, Vol. 86, No. 2, (Sep., 1999), 481-517.

82. Albert O. Hirschman, Exit, Voice, and Loyalty. Responses to Decline in Firms, Organizations, and States. (Cambridge: Harvard University Press, 1970), 30-33.

83. Armando Navarro, The Immigration Crisis. Nativism, Armed Vigilantism and the Rise of a Countervailing Movement, (Altamira Press, 2009), 9. 
84. Roberto Lovato, Juan Crow in Georgia, The Nation, May 26, 2008.

85. Full text of the legislation (Public Law No: 109-367) is available at the U.S. Library of Congress at: http://thomas.loc.gov/cgi-bin/bdquery/z?

d109:HR06061:@@@Lsumm2=m\&|TOM:/bss/d109query.html (accessed October 15, 2009).

86. Hirschman, Exit, Voice, and Loyalty, 34.

\section{ABSTRACTS}

This article analyzes the concept of political loyalty in the context of mass migration flows to the U.S. After exploring the evolving notion of political loyalty, it provides a brief historical background of concerns about the political disloyalty of immigrants in the U.S. Based on a review of current literature and surveys, the case of Mexican immigrants as the biggest immigration group is then analyzed in more detail. It is argued that even though immigrants from Mexico are at times accused of potential disloyalty, they can be considered quite loyal, depending on the selected indicators of loyalty used. This paradox is explained by the expansive use of the notion of political loyalty by modern-day U.S. Nativists. The conclusion argues for a more inclusive concept of political loyalty, which would be better suited for the present-day era of large-scale trans-border movements.

1. Introduction

2. A Definition of Political Loyalty

3. Loyalty Concerns and Immigration in the U.S. Context

4. Case Study: Review of loyalty concerns related to immigrants from Mexico

4.1 Allegations of disloyalty

4.2 Basic characteristics of immigrants from Mexico

4.3 Measuring the loyalty of Mexican immigrants

5. Conclusion: Loyalty Concerns and Immigration

\section{AUTHOR}

\section{KRYSTOF KOZAK}

Krystof Kozak, Department of American Studies, Institute for International Studies, Charles University, Prague 